\title{
Réplica a: La unidad de la filosofía de Heráclito
}

\author{
José Molina \\ Universidad Nacional Autónoma de México
}

El mismísimo Sócrates dijo a Euripides respecto de la obra heracliteana: "lo que entendi es excelente, y pienso que también lo que no entendi; sólo que se precisa de algún buzo profesional"'. De manera, que el solo hablar de Heráclito es tarea en sí misma encomiable. Reponiéndonos de la tristeza por lo que se ha perdido, los fragmentos de la obra de Heráclito nos han llegado bajo la mirada de quienes los citan, como se verían a través de una lente que a veces los engrandece, y a veces los deforma. Tienen la ventaja de hacernos ver lo que de otro modo acaso hubiera pasado inadvertido, pero debemos cuidarnos tanto de la deformación que han sufrido por el contexto en el que están citados, como por la deformación que siguen experimentando bajo nuestra mirada. Por otra parte, un - fragmento siempre invita a la reconstrucción, a inventar de nuevo el conjunto del que forma parte, y pese a la existencia de otros fragmentos del mismo conjunto, en el caso de Heráclito, son las indeterminaciones las que se multiplican. ¿Cómo los ha visto Enrique Hülsz? Da la impresión que no quiso perder ninguno de los puntos de vista, dada la bibliografia en que se apoya; en muchos sentidos sigue de cerca a Kahn, quien también había hablado de la densidad y de la resonancia de los fragmentos. Quiere abarcar todos los fragmentos. En ellos se mueve como ese buzo del que hablaba Sócrates, si hemos de creerle a Diógenes Laercio; y como buzo prudente, matiza todas sus afirmaciones, a fin de poder salir a flote, yo quiero ver si lo consiguió.

' D. L. II, 22. 
De acuerdo con lo que hemos escuchado, la unidad de la obra heracliteana, entendida como la unidad formal de los fragmentos, ha dado lugar a múltiples reconstrucciones que giran básicamente sobre los logoi mencionados por Diógenes Laercio. En este sentido, tal vez cabria anotar que La vida de los filósofos más ilustres, como se conoce su obra, se parece, por decir lo menos, a Casandra, esa profetiza que recitaba sus oráculos, condenada por Apolo a que nadie los creyera. Así, a Diógenes nadie le cree, aunque todos lo citan. De la mano de Enrique Hülsz podemos también no creerle, y pensar que la división referida de la obra de Heráclito es exógena e impuesta por la partición que de la filosofia hacía el helenismo. Sin embargo, también se puede y se debe atender dicha división, precisamente por no concordar con la división de la filosofia en fisica (o metafisica), ética y lógica, típica desde el platónico Polemón, sancionada por Zenón de Citio y permanente ya en tiempos del mismo Diógenes ${ }^{2}$. Podríamos creer que la falta de correspondencia entre la división de la obra de Heráclito y la división de la filosofia en su tiempo, en especial el logos teológico -al que Enrique Hülsz muestra ciertas reticencias-, sea precisamente la razón de que Diógenes haya creido necesario consignarla. De cualquier manera, Diógenes Laercio apunta a la unidad de la obra de Heráclito, pero también existe el testimonio según el cual desde su composición la obra parecía incompleta, y unas partes diferían de otras ${ }^{3}$; de manera que aun suponiendo que pudiéramos reconstruir los argumentos que se implican en los fragmentos, estamos limitados a llegar inevitablemente a un callejón sin salida o a una salida falsa. La verdad es que no sabemos si podemos reconstruir plausiblemente esa unidad, y acaso tampoco sea lo más importante. Se puede reconstruir, por ejemplo, el Partenón, pero, ¿sería deseable? Reconstruir un espacio no es reconstruir un ambiente; la Atenas de Pericles se ha ido para siempre.

De Heráclito, quedan esos fragmentos, nada más, pero nada menos. Tenemos la alternativa de dejarlos seguir aguijoneando nuestro espíritu, o la de llegar a contentarnos con una reconstrucción

\footnotetext{
${ }^{2}$ D. L. I, 18

${ }^{3}$ D. L. II, 8.
} 
que nos haga precisamente situarnos entre aquellos a quienes Heráclito llamaba dormidos y sordos, eso sí llenos de erudición y de la polimathía que no enseña entendimiento. La otra unidad, ya no formal, sino temática, en la obra de Heráclito es la que más ha consumido las horas que Enrique Hülsz se ha sumergido en esas aguas profundas, para seguir con la imagen utilizada por Sócrates. La clave, nos dice, está en el logos. La estructura del ser se corresponde con la estructura del pensar; que es la estructura del decir y del contradecir, que debiera ser la estructura del poder; la actividad por la cual la mente del hombre avanza en la comprensión del mundo está en armonía con la estructura del mundo que se percibe. Pero esa armonía sólo se capta mediante un acto, digamos, holístico y trascendente, capaz de mirar al mundo no en el ámbito de los particulares, sino desde fuera como un todo.

A partir de estos argumentos se puede pensar en muchas cosas, y se pueden preguntar otras varias. Me viene a la cabeza Wittgenstein, si es verdad que él dijo eso de que "el límite de mi mundo es el límite de mi lenguaje", con la salvedad de que acaso en Wittgenstein hay tantos mundos como individuos, mientras que en Heráclito, según lo ve Enrique Hülsz, sólo hay un único mundo, un solo logos que le dio principio, que lo comprende, que lo expresa, y que debería gobernarnos. Me pregunto, y me imagino que también ustedes, y acaso nos lo aclare el propio Enrique Hülsz, en qué se distingue el logos de Heráclito como él lo ve, de ese logos de los estoicos, que también era y no era Zeus, destino, necesidad, principio del cosmos, según el cual sucede todo, capaz de ser comprendido por el hombre y de ser expresado por su lenguaje. Llamó poderosamente mi atención la opinión del gramático Diódoto, que menciona Hülsz; afirma aquél que la obra de Heráclito es primordialmente una obra de carácter político 4 . Cabe recordar que por "gramático" debe entenderse "filólogo". Y estoy tentado a darle la razón por simple simpatía con el gremio, dado que no soy ni pretendo ser filósofo. Se trata de un intento de desmontar el enfoque predominante, según el cual Heráclito es un filósofo de la naturaleza. Debe tomarse en cuenta que la interpretación de Diódoto puede, a fin de sernos más provechosa,

${ }^{4}$ D. L. II. 
oponérsele no sólo a la interpretación cosmológica, sino a aquella que concede al logos una categoría revestida exageradamente de metafisica y de trascendencia, tal como lo leyeron acaso los estoicos en el pasado ${ }^{5}$; o como pudieron leerlo Hegel o Nietzche, o como puede leerlos cualquiera de nosotros. Esto no significa quitarle a Heráclito importancia alguna ni como humanista ni como mero filósofo; significa solamente ubicarlo en su época, en su ambiente, y desmitificarlo. ¿Qué pasaría si tomamos más en serio a Diódoto? A la luz de la ponencia de Enrique Hülsz, la visión política en su plena significación, sin atenuarla tomándola como antropológica, parecería casi un desvario. Personalmente me hubiera gustado tomar más en serio a Diódoto, pero tuve la suerte, ignoro si buena o mala, de dar con el libro de Antonio Capizzi, Eraclito e la sua leggenda, a quien Enrique Hülsz sin duda conoce, ya que lo cita en su bibliografia sumaria. Imaginemos tan sólo, que los fragmentos donde Heráclito despotrica contra Homero, Hesíodo o Arquíloco, no son más que una disputa entre su expresión en prosa y la recitación poética. Con frases que a todos nos han conmovido, por ejemplo: "es difícil luchar con el deseo, lo que quiera lo compra con el alma"; la guerra es padre y rey de todas las cosas", se trata de impulsar una campaña de austeridad en el gobierno, y hacer una exhortación militar proselitista en contra del imperio de Dario, quien habría incluso en ese tiempo asolado Jonia y arruinado a Mileto. En esta reconstrucción de Capizzi, el fragmento primero ${ }^{6}$ adquiere totalmente otro significado: el logos que existe siempre, no es la razón que le da existencia al cosmos; se trata simplemente de una legislación, cuyo autor es Hermodoro, el mismo a quien, según otros fragmentos, los efesios habian desterrado y cuya ley habian despreciado. ¿Qué significa que los hombres se hagan incapaces de comprensión antes de escuchar y una vez que han escuchado? Imaginemos a un juez o jueces analfabetas, como era normal en aquellos tiempos: Al llegar el

5 Debe tenerse en cuenta que un estoico como Crisipo, según el testimonio de Cicerón (cfr. Cic., Nat. D., I, 39-41), buscaba, adaptando la interpretación de las fábulas, que incluso Homero y otros de los autores antiguos, como Orfeo, Museo y Hesiodo, fueran estoicos.

${ }^{6}$ Cabe hacer notar que se atribuye este lugar a ese fragmento, tesis de la que parece querer separarse Hulsz, gracias al testimonio de Aristóteles en su Retórica, de donde también sabemos que a Heráclito se le acusaba de "oscuro". 
acusado, hacían leer esa legislación, nueva en ciertos sentidos, para vèr de qué manera se aplicaba al caso particular. A pesar de tener experiencia, parecen no tenerla: se vuelve necesario repetirla y explicarla según el caso y de acuerdo con el espíritu de la ley. Así se entiende que quienes no advierten las cosas cuando están despiertos igual que las olvidan cuando están dormidos, sean en el texto otros hombres, distintos de aquellos a quienes Heráclito explica la ley de Hermodoro. Por lo demás, para Capizzi, el logos como razón universal, el correr de todas las cosas, la cosmología del fuego, ya han sido interpretaciones de los fragmentos heracliteanos refutadas por estudiosos como Reinhardt, Kirk, Calogero, Mc Diarmid, Cherniss y Havelock ${ }^{7}$. Probablemente Kahn no tuvo en cuenta la sugerencia de Capizzi, debido a la simultaneidad de los trabajos. Obviamente Capizzi aporta más datos, más testimonios, más argumentos para apuntalar su tesis. Muy brevemente expuse aquí esta reconstrucción, heterodoxa e impopular, si quieren, sólo para hacer notar que esos mismos fragmentos pueden ser vistos de una manera totalmente distinta, pero igualmente válida, a pesar de que nuestro celo humanistico y filosófico se vea, una vez más, golpeado. Es normal que esto suceda. Lo mismo ocurre con la frase por todos conocida: "soy humano, y nada de lo humano me es ajeno", que suele ya sin remedio cargarse de humanismo, pero que en el texto original de Terencio no significa más que la expresión de una curiosidad malsana ${ }^{8}$. Acaso sea útil comparar los fragmentos de Heráclito con alguna pieza artística: un edificio antiguo, una escultura, una pintura. Apreciamos la Afrodita de Melos, o Venus de Milo, como se la conoce, aun sin brazos; también esperamos que ningún "genio" termine Los Esclavos de Miguel Ángel. Imaginemos cómo hubiera sido reconstruido, si sólo se hubieran conservado la cabeza y las manos del David del mismo autor. Por lo demás, el peor restaurador de una pintura, dicen los entendidos, es otro pintor. Lo que se entrega a la restauración, no es la obra de arte, sino la materia

7 CAPIzZI, A.: Eraclito e la sua leggenda. Proposta di una diversa letttura dei frammenti, Roma: Edizioni dell'ateneo \& Bizzari (Filologia e critica, 34/Istituto di filologia classica, Università di Urbino) 1979, p. 9.

${ }^{8}$ Cfr. AlBRECHT, M.: Historia de la literatura romana. Desde Andronico hasta Boecio, trads. Dulce Estefanía y Andrés Pociña. Madrid: Herder 1997, vol. I, p. 239. 
de la obra de arte. Ignoro, lo confieso, si ocurre lo mismo en el caso de la filosofia. Kahn teme que el resultado sea similar al de pelar una cebolla. Por mi parte, no creo que haya buenas o malas reconstrucciones, sino afortunadas y desafortunadas. En todo caso, todas son buenas, si somos capaces de desprendernos de ellas y de volver de inmediato a los fragmentos; cualquiera es pésima, si nos aferramos a ella. Regresando a la comparación con las obras de arte, el criterio actual es que toda restauración debe ser removible. Imagino los fragmentos como un rompecabezas de muchas soluciones, si existiera, que pueden dar siempre pretexto a que nos sigamos reuniendo. 
Copyright of Tópicos. Revista de Filosofía is the property of Universidad Panamericana and its content may not be copied or emailed to multiple sites or posted to a listserv without the copyright holder's express written permission. However, users may print, download, or email articles for individual use. 